\title{
UPAYA PENINGKATAN PRESTASI BELAJAR PENJASORKES MELALUI MODEL KOOPERATIF TIPE JIGSAW DI SMAN 4 TEBO TAHUN PELAJARAN
} 2019/2020

\author{
SURYONO \\ SMA Negeri 4 Tebo Provinsi Jambi \\ suryono509@yahoo.com
}

\begin{abstract}
ABSTRAK
Penelitian ini bertujuan untuk meningkatkan prestasi belajar Penjasorkes melalui penerapan model kooperatif tipe Jigsaw pada materi kebugaran Jasmani di SMA Negeri 4 Tebo semester I pada tahun pelajaran 2019/2020. Penelitian tindakan kelas ini dilakukan melalui 2 siklus dan pada setiap siklus meliputi bagian perencanaan, pelaksanaan, observasi dan refleksi. Sedangkan untuk mengaktifkan siswa dalam penelitian ini, peneliti menggunakan lembar kerja yang diberikan kepada siswa dalam kerja kelompok yang menjadi subyek penelitian tindakan kelas ini adalah siswa kelas XI IPS 1 SMA Negeri 4 Tebo semester I pada tahun pelajaran 2019/2020, sedangkan obyek adalah pembelajaran penjasorkes materi kebugaran Jasmani yang diajarkan dengan cara mengaktifkan siswa melalui model kooperatif tipe Jigsaw. Dari penelitian yang diadakan dengan meneliti kondisi awal siswa yang diukur dengan alat tes tulis dan hasil penelitian tindakan kelas dengan 2 siklus terlihat adanya peningkatan hasil yang dicapai. Siswa dalam menguasai materi yang diberikan peningkatan penguasaan materi ini mulai dari siklus I siswa dapat meningkat sebesar 32,14\% dari kondisi awal, sedangkan dari siklus I setelah dilakukan tindakan pada siklus II meningkat sebesar 14,29\%.
\end{abstract}

Kata Kunci: prestasi belajar, strategi pembelajaran aktif, penjasorkes

\section{PENDAHULUAN}

Keberhasilan tujuan pembelajaran ditentukan oleh banyak faktor diantaranya adalah faktor guru dalam melaksanakan proses belajar mengajar, karena guru secara langsung dapat mempengaruhi, membina dan meningkatkan kecerdasan serta keterampilan siswa. Untuk mengatasi permasalahan di atas dan guna mencapai tujuan guruan secara maksimal, peran guru sangat penting dan diharapkan guru memiliki cara/model mengajar yang baik dan mampu memilih model pembelajaran yang tepat dan sesuai dengan konsep-konsep mata pelajaran yang akan disampaikan (Maisarah, 2019).

Pembelajaran adalah proses, cara, menjadikan orang atau makhluk hidup belajar. Sedangkan belajar adalah berusaha memperoleh kepandaian atau ilmu, berubah tingka laku atau tanggapan yang disebabkan oleh pengalaman. pembelajaran adalah proses pengelolaan lingkungan seseorang yang dengan sengaja dilakukan sehingga memungkinkan dia belajar untuk melakukan atau mempertunjukkan tingkah laku tertentu pula (Ainin, 2012). Sedangkan belajar adalah suatu peoses yang menyebabkan perubahan tingkah laku yang bukan disebabkan oleh proses pertumbuhan yang bersifat fisik, tetapi perubahan dalam kebiasaan, kecakapan, bertambah, berkembang daya pikir, sikap dan lain-lain. Proses belajar mengajar merupakan suatu inti dari proses guruan secara keseluruhan dengan guru sebagai pemegangn peran utama. Proses belajar mengajar merupakan suatu proses yang mengandung serangkaian perbuatan guru dan siswa atas dasar hubungan timbal balik yang berlangsung dalam situasi edukatif untuk mencapai tujuan tertentu. Interaksi atau hubungan timbal balik antara guru dan siswa itu merupakan syarat utama bagi berlangsungnya proses belajar mengajar (Mulyadi, 2018).

Belajar dan prestasi belajar merupakan kegiatan yang tidak terpisahkan dalam kehidupan manusia, dengan belajar manusia dapat mengembangkan potensi yang dimilikinya. Tanpa belajar manusia tidak mungkin dapat memenuhi kebutuhan- kebutuhannya. Belajar merupakan perubahan tingkah laku dengan serangkaian kegiatan misalnya membaca, mengamati, mendengarkan, meniru dan sebagainya (Wijayani, dkk, 2017). Prestasi belajar dapat diartikan sebagai hasil yang dicapai oleh individu setelah mengalami suatu proses belajar 
dalam jangka waktu tertentu. Prestasi belajar juga diartikan sebagai kemampuan maksimal yang dicapai seseorang dalam suatu usaha yang menghasilkan pengetahuan atau nilai-nilai kecakapan (Siagian, 2015).

Prestasi belajar adalah perubahan tingkah laku yang diharapkan pada siswa setelah dilakukan proses belajar mengajar. Sedangkan belajar merupakan proses aktif sehingga dengan belajar seseorang memperoleh sesuatu yang baru, dengan adanya sesuatu baru tersebut menyebabkan yang belajar tersebut memperoleh perubahan tingkah laku (Pratiwi, 2017). Berdasarkan penjelasan tersebut maka prestasi belajar merupakan bukti keberhasilan siswa dalam penguasaan ketrampilan dan pengetahuan yang dikembangkan oleh mata pelajaran dalam proses belajar mengajar dimana yang lazim dilakukan dengan tes atau angka nilai-nilai yang diberikan oleh guru, dalam artian siswa dapat dipengaruhi oleh beberapa faktor baik yang menyangkut kondisi internal maupun eksternal (Syafi'I, dkk, 2018).

Dalam proses pembelajaran model pembelajaran sangat penting dilaksanakan dalam rangka mencapai tujuan secara maksimal. Model pembelajaran aktif adalah suatu model pembelajaran yang diberikan kesempatan kepada siswa untuk berperan aktif dalam proses pembelajaran (mencari informasi, mengolah informasi, dan menyimpulkannya) dengan menyediakan lingkungan belajar yang membuat siswa tidak tertekan dan senang melaksanakan kegiatan pembelajaran (Yunus, dkk, 214). Model pembelajaran yang aktif adalah model pembelajaran yang mampu membangkitkan keaktifan dan kerjasama siswa dalam kegiatan mencari tahu atau belajarnya. Model pembelajaran seperti ini biasanya tersedia dalam model pembelajaran kooperatif (Fathurrohman, 2015).

Alasan mengapa model pembelajaran aktif memungkinkan untuk diterapkan dan dapat meningkatkan prestasi belajar, karena menurut peneliti strategi ini lebih banyak membawa suasana gembira dan menyenangkan. siswa aktif melakukan kegiatan baik secara individu maupun kelompok, Mereka mempunyai kesempatan yang sama untuk sukses dalam pembelajaran. Belajar aktif merupakan langkah cepat, menyenangkan, dan menarik, dalam pembelajaran aktif guru sebagai fasilitator bukan pemberi ilmu (Nurdyansyah, dkk, 2018).

Selama ini guru yang cenderung memperhatikan kelas secara keseluruhan, tidak perorangan atau kelompok, sehingga perbedaan individual kurang mendapat perhatian. Gejala yang lain terlihat masih banyak guru yang menggunakan strategi dan model pembelajaran yang belum maksimal (Nopiyanto, 2020). Pembelajaran yang kurang memperhatikan perbedaan individual siswa didasarkan pada keinginan guru, maka akan sulit untuk dapat menghantarkan siswa kearah pencapaian tujuan pembelajaran. Kondisi seperti ini yang pada umumnya terjadi pada pembelajaran konvensional, khususnya yang terlihat di lapangan yaitu proses pembelajaran yang dilaksanakan di SMA Negeri 4 Tebo.

Proses belajar mengajar khususnya di SMA Negeri 4 tebo, tenaga pengajar sudah memadai serta materi yang diberikan sudah ditetapkan dan disesuaikan menurut garis-garis besar program pengajaran yang berlaku. Namun dalam pelaksanaannya belum menampakan keberhasilan dalam menerima pelajaran khususnya bidang studi Pendidikan Jasmani Olahraga dan Kesehatan (Penjasorkes). Rendahnya prestasi belajar siswa tersebut bisa juga disebabkan karena strategi pembelajaran yang digunakan dalam kegiatan belajar mengajar selama ini belum diterapkan secara maksimal. Pendidikan jasmani merupakan aktifitas olahraga dan kesehatan yang di ajarkan di sekolah memiliki peranan sangat penting, memberikan kesempatan kepada siswa untuk terlibat langsung dalam berbagai pengalaman belajar melalui aktifitas jasmani, olahraga harus di lakukan secara sistematis, di arahkan untuk membina pertumbuhan fisik dan pengembangan psikis yang lebih baik.

Dari hasil pra survey di SMA Negeri 4 tebo tanggal 2 Agustus 2019, Upaya peningkatan kualitas proses pembelajaran pendidikan jasmani di sekolah belum berjalan sebagai mana yang diharapkan. Hal tersebut dapat dilihat dari pengalaman penulis bahwa siswa masih mengalami kesulitan dalam memahami konsep dan penguasaan teknik dasar suatu cabang olahraga, demikian pula pendidik masih mengalami kesulitan dalam menanamkan konsep dan penguasaan teknik dasar olahraga sehingga berakibat pada rendahnya hasil belajar. 
Pembelajaran aktif akan berpengaruh terhadap kualitas hasil dari sebuah pembelajaran. aktifitas siswa yang kurang terlibat aktif dalam proses pembelajarannya. Pada kegiatan inti pembelajaran, ketika penyajian konsep hanya sebagian siswa saja yang dapat terlibat lebIh aktif, dalam arti dapat menjawab pertanyaan atau mengemukakan pendapat atau gagasan serta mempraktikan dihadapan pendidik, padahal pendidik sudah membuka kesempatan untuk bertanya, menjawab atau memberi tanggapan atas penjelasan yang sudah disampaikan.

Berdasarkan pengamatan di lapangan secara umum proses pembelajaran Pendidikan Jasmani Olahraga dan Kesehatan (Penjasorkes) di SMA Negeri 4 tebo, bahwa guru Pendidikan Jasmani Olahraga dan Kesehatan (Penjasorkes) dalam proses pembelajaran belum melaksanakan strategi pembelajaran aktif. Melihat kenyataan tersebut, guru masih kurang melibatkan keaktifan siswa dalam proses pembelajaran, model mengajar masih mengandalkan model ceramah sehingga menimbulkan kejenuhan belajar.

Untuk mengatasi permasalahan tersebut, maka model yang ingin diterapkan peneliti adalah menggunakan model kooperatif tipe Jigsaw agar memberikan kesempatan kepada seluruh siswa untuk saling berinteraksi terlibat aktif, dan dapat meningkatkan hasil belajar siswa agar lebih aktif dalam melakukan praktek terhadap materi yang diberikan, serta terjalinnya sosial dan hubungan emosional terhadap siswa lainnya dan terhadap guru (Rosyidah, 2016). Jigsaw merupakan salah satu tipe pembelajaran kooperatif yang mendorong siswa aktif dan saling membantu dalam menguasai materi pelajaran untuk mencapai prestasi yang maksimal. Sehingga memberikan kesempatan kepada seluruh siswa untuk saling berinterksi, terlibat aktif, berani dalam menyampaikan pendapat dan ide-idenya, dapat meningkatkan psikomotorik siswa agar lebih aktif dalam melakukan praktek terhadap materi yang diberikan, serta terjalinnya sosial dan hubungan emosional terhadap siswa dengan teman temannya dan juga guru (Trisianawati, dkk, 2016).

Jigsaw merupakan model pembelajaran yang mengutamakan pengembangan berfikir kreatif dan belajar bekerja sama dengan teman. tipe jigsaw adalah salah satu pembelajaran kooperatif dimana pembelajaran melalui kelompok kecil siswa yang bekerja sama dalam memaksimalkan kondisi belajar untuk mencapai tujuan pembelajaran dan mendapatkan pengalaman belajar yang maksimal, baik pengalaman individu maupun pengalaman kelompok (Putra, dkk, 2018). Dalam pembelajaran siswa diberikan kesempatan untuk berkolaborasi dan bekerja sama dengan teman sebaya dalam bentuk diskusi kelompok dalam memecahkan suatu permasalahan yang diberikan oleh guru. Pada dasarnya tipe jigsaw membagi materi yang cukup luas menjadi komponen-komponen kecil yang disebarkan kepada setiap orang dalam suatu kelompok, sehingga menjadi subtopik-subtopik yang perlu dipelajari oleh setiap individu dalam kelompoknya. Setiap siswa bertanggung jawab atas subtopik yang diperoleh dari hasil pembagian oleh guru (Nurfitriyanti, 2017).

\section{METODE PENELITIAN}

Sebelum mengadakan tindakan pada penelitian ini, maka peneliti mengadakan observasi cara mengajar guru dalam kelas serta mencari data penguasaan materi kebugaran jasmani dari siswa. Seperti telah dijelaskan sebelumnya bahwasanya pada penelitian tindakan kelas ini dilakukan dalam 2 siklus namun apabila dari 2 siklus yang direncanakan masih ada masalah yang harus dipecahkan maka dapat dilanjutkan dengan siklus berikutnya.

Penelitian ini dilaksanakan di SMA Negeri 4 Tebo dengan populasi penelitian yakni kelas XI SMA Negeri Tebo. Adapun Subjek penelitian yakni kelas XI IPS 1 SMA Negeri 4 Tebo tahun pelajaran 2019/2020 berjumlah 34 orang siswa.

Pelaksanaan langkah penelitian yang akan dilakukan oleh peneliti adalah sebagai berikut: (1) Peneliti menyusun rencana pelaksanaan pembelajaran (RPP) yang berkaitan dengan materi kebugaran jasmani, (2) Peneliti merancang skenario pembelajaran yang dapat mengaktifkan siswa secara kelompok, (3) Peneliti merancang alat pengumpulan data yang berupa tes dan digunakan untuk mengetahui pemahaman kemampuan siswa yang berkaitan 
dengan kebugaran jasmani. Adapun prosedur penelitian tindakan pada tiap siklus terdiri dari perencanaan, pelaksanaan, observasi, dan refleksi.

\section{HASIL DAN PEMBAHASAN}

Sebelum penelitian tindakan kelas ini dilaksanakan maka peneliti mengadakan observasi dan pengumpulan data dari kondisi awal kelas yang akan diberi tindakan, yaitu kelas XI IPS 1 SMA Negeri 4 Tebo tahun pelajaran 2019/2020. Pengetahuan awal ini perlu diketahui agar kiranya penelitian ini sesuai dengan apa yang dirapkan oleh peneliti, apakah benar kiranya kelas ini perlu diberikan tindakan yang sesuai dengan apa yang diteliti oleh peneliti yaitu penerapan model kooperatif tipe Jigsaw untuk meningkatkan prestasi hasil pembelajaran kebugaran jasmani. Setelah didapatkan data kondisi awal berupa masih kurangnya prestasi belajar siswa. Maka peneliti mencoba menerapkan model kooperatif tipe Jigsaw dengan harapan adanya perubahan prestasi belajar siswa.

\section{Siklus I}

\section{Perencanaan}

Untuk melakukan penelitian pada siklus I ini peneliti merencanakan tindakan yang meliputi: (1) Membuat rencana pelaksanaan pembelajaran (RPP) (2) Membuat rancangan program pengajaran yang digunakan untuk belajar kelompok dan setiap siklus kelompok terdiri dari 6-7 orang. Rancangan program yang dibuat digunakan untuk pengajaran 2X45 menit (3) Membuat lembar kerja siswa yang digunakan untuk mengaktifkan siswa dalam belajar dengan penugasan tahap yang membawa siswa berdialog (4) Membuat alat evaluasi yang digunakan untuk mendapatkan tindakan dengan menggunakan model kooperatif tipe Jigsaw (5) Membuat solusi dan langkah untuk disampaikan pada siswa berkaitan kelemahan siswa dalam menyelesaikan soal yang telah diujikan oleh guru.

\section{Pelaksanaan}

Pelaksanaan tindakan kelas pada siklus I dilaksanakan pada tanggal 21 Agustus 2019. Peneliti melakukan kegiatan sesuai dengan apa yang telah direncanakan, dimulai dengan penjelasan pada siswa tentang kegiatan yang harus dilakukan oleh siswa dalam mengikuti kegiatan. Berdasarkan informasi yang telah disampaikan peneliti pada saat observasi pengajaran yang dilakukan maka peneliti menyampaikan kelemahan dan kekurangankekurangan yang dilakukan siswa dalam menyelesaikan materi percakapan yang diujikan dengan metode Tanya jawab.

Peneliti membagikan lembar kerja siswa yang telah dirancang dan disusun oleh peneliti untuk diselesaikan siswa secara keseluruhan dan peneliti berkeliling untuk mengamati cara kerja dan dialog dengan penjasorkes, serta membantu siswa yang mengalami masalah dalam menyelesaikan lembar kerja yang dibagikan. Sambil berkeliling peneliti mencatat hambatanhambatan yang terjadi pada saat siswa mengerjakan lembar kerja siswa tersebut selain itu peneliti juga mencatat siswa-siswa yang aktif dan mampu dalam menyelesaikan masalah yang diberikan oleh peneliti.

Hasil pengamatan Setelah lembar kerja siswa yang mengarahkan siswa untuk menemukan sesuatu masalah materi kebugaran dibagikan maka tampak siswa antusias dalam mengerjakan lembar kerja tersebut. Pada pengerjaan lembar kerja yang dibagikan ini tampak terlihat adanya siswa yang bermain-main ataupun asyik mengerjakan pekerjaan yang lain, semuanya asyik dalam mengerjakan lembar kerja yang dibagikan. Pada pelaksanaan pengerjaan lembar kerja tersebut tampak adanya siswa yang mengalami hambatan dalam menyelesaikan bertanya pada teman terdekatnya namun ada pula siswa yang mengalami hambatan dalam mengajarkan lembar kerja tersebut langsung bertanya pada peneliti.

Pada tes tulis yang diberikan setelah diuji oleh guru pengajar/peneliti didapatkan hasil sebagai berikut: dari 34 siswa yang ada, 2 siswa mendapatkan nilai 75, sedangkan 32 siswa telah mendapatkan niai di atas tuntas, hal ini berarti $85.7 \%$ telah mampu menuntaskan materi kebugaran jasmani. 


\section{Refleksi}

Dengan melihat titik lemah yang terjadi pada sebagian kecil siswa berkenaan melakukan senam kebugaran, maka perlu diberikan penjelasan yang mendasar pada siswa-siswa yang mengalami hambatan dengan memanfaatan teman yang telah lancar senam kebugaran dalam penjasorkes. Mendata siswa yang mempunyai kemampuan lebih dan mampu untuk menyampaikan materi dengan penjasorkes, yang dikuasainya bersama temannya perlu dibentuk kelompok-kelompok kecil yang terdiri dari 4 siswa untuk berkolaborasi dalam belajar dan dipimpin oleh anak yang punya kemampuan lebih dan mampu menyampaikan materi yang dikuasainya. Perlu dibuat suatu catatan besar yang siswa sering salah dalam memahami senam kebugaran untuk ditindaklanjuti pada tindakan berikutnya.

\section{Siklus II}

\section{Perencanaan}

perencanaan siklus II ini peneliti merencanakan tindakan sebagai berikut: (1) Membuat kelompok yang terdiri dari 4 siswa dan masing-masing kelompok dipimpin oleh siswa yang dipilih dari anak yang punya kemampuan lebih dan mampu memimpin. (2) Membuat rencana pembelajaran (RPP) materi kebugaran jasmani yang dipergunakan selama bagi pengajaran selama 90 menit. (3) Membuat lembar kerja yang digunakan untuk diskusi kelompok. (4) Merencanakan alat evaluasi yang berupa soal tes yang digunakan untuk mengukur kemampuan siswa.

\section{Pelaksanaan}

Pelaksanaan tindakan Seperti yang telah direncanakan maka peneliti melaksanakan tindakan siklus II pada tanggal 8 September 2019 dengan materi kebugaran jasmani pada tindakan di siklus II diawali penjelasan kepada siswa tentang prosedur yang akan dilaksanakan. Peneliti membagi kelompok yang terdiri dari 4 siswa dan menentukan ketua dari masingmasing kelompok tersebut, selanjutnya siswa berkumpul dengan kelompoknya maka peneliti membagikan lembar kerja siswa untuk didiskusikan bersama dari masing-masing kelompok, pada saat siswa mulai berdiskusi peneliti berkeliling untuk mencatat kesalahan-kesalahan yang dilakukan kelompok untuk dibimbing serta mencatat siswa yang pasif agar bisa diajak aktif oleh kelompoknya.

\section{Observasi}

Hasil pengamatan Pada pelaksanaan siklus II tampak sekali bahwa siswa sangat antusias dalam mengerjakan tugas kelompok, semua siswa terlihat aktif bersama kelompok dalam menyelesaikan lembar kerja yang diberikan peneliti. Pada saat diskusi pembahasan materi yang diberikan satu kelompok untuk ditanggapi oleh kelompok lain kadang terlihat perbedaan pola fikir dari masing-masing individu dalam menyampaikan ide pemecahan masalah yang diberikan.

Berdasarkan evaluasi yang dilaksnakan setelah dikoreksi didapatkan hasil yang sesuai dengan indikator pencapaian hasil yang dharapkan karena dari 34 siswa kelas XI IPS 1 tersebut tidak ada siswa yang mendapatkan nilai di bawah batas ketuntasan minimal sehingga persentase siwa yang telah tuntas adalah $100 \%$.

\section{Refleksi}

Dari hasil evaluasi yang diberikan selama 1 jam pelajaran atau 45 menit ternyata 34 siswa telah mampu mendapatkan nilai di atas batas ketuntasan minimal namun masih terlihat beberapa kesalahan terkait materi kebugaran jasmani yang dilakukan oleh siswa dikarenakan faktor kurang terbiasanya siswa dalam melakukan senam kebugaran. Keaktifan dari siswa secara keseluruhan telah sesuai yang diharapkan oleh peneliti karena dalam mengerjakan lembar kerja secara kelompok ini $100 \%$ telah aktif dalam pembahasan lembar kerja yang diberikan.

\section{Deskripsi Antar Siklus}


Berdasarkan hasil pelaksanaan tindakan mulai pemantauan keadaan awal hingga pelaksanaan tindakan pada siklus II maka dapat digambarkan seperti di bawah ini:

Tabel 1. Deskrifsi Antar Siklus

\begin{tabular}{l|l|l}
\hline \multicolumn{3}{c|}{ Persentase yang dicapai } \\
Awal & Siklus I & Siklus II \\
$53,57 \%$ & $85,71 \%$ & $100 \%$ \\
\hline
\end{tabular}

Dari tabel antar siklus di atas tampak adanya hasil dari masing-masing indikator yang harus dikuasai siswa setelah diberikan tindakan model kooperatif tipe Jigsaw mengalami peningkatan yang luar biasa. Jika siswa nyaman dalam belajarnya maka akan diperoleh prestasi hasil belajar yang baik. Dalam hal ini sebagian besar aktifitas pembelajaran perpusat pada siswa untuk memecahkan masalah atau tugas, dengan interaksi yang efektif dimungkinkan semua aggota kelompok dapat menguasai materi secara setara.

\section{Respon Siswa}

Data respon siswa tentang tanggapan terhadap penerapan model kooperatif tipe Jigsaw dalam siklus I disajikan pada table 2 sebagai berikut:

Tabel 2. Data Respon Siswa pada Siklus I

\begin{tabular}{llll} 
Nilai & Jumlah Siswa & Jumlah Nilai & Rata-rata \\
$85.1-100$ & - & - & - \\
$65.1-85.0$ & 13 & 1027.5 & $68.5 \%$ \\
$45.1-65.0$ & 11 & 654.4 & $54.7 \%$ \\
$25.1-45.0$ & 10 & 471 & $47.1 \%$ \\
$0.0-25.0$ & - & - & - \\
Jumlah & & & $55.44 \%$ \\
Kategori & & & Cukup \\
\hline
\end{tabular}

Dari data analisis respon siswa di atas diperoleh nilai 00-25 sebanyak 0, nilai 25.1-45 sebanyak 10 siswa, nilai 45.1-65 sebanyak 11, nilai 65.1-85 sebanyak 13, dan nilai

85.1-100 sebanyak 0 orang. Sehingga setelah persentase didistribusikan ke dalam rumus memperoleh persentase sebesar nilai 00-25 sebanyak 0\%, nilai 25.1-45 sebanyak $43.1 \%$, nilai 45.1-65 sebanyak3 4.7\%, nilai 65.1-85 sebanyak 68.5\%, dan nilai 85.1-100 sebanyak 0 orang. Dengan jumlah nilai rata-rata respon $55.4 \%$ sehingga setelah dikomversikan ke dalam tabel termasuk kategori cukup.

Sedangkan data respon siswa tentang tanggapan terhadap penerapan model kooperatif tipe Jigsaw dalam siklus II disajikan pada table 3 di bawah ini:

Tabel 2. Data Respon Siswa pada Siklus II

\begin{tabular}{llll} 
Nilai & Jumlah Siswa & Jumlah Nilai & Rata-rata \\
$85.1-100$ & 17 & 1602 & $90 \%$ \\
$65.1-85$ & 7 & 356.8 & $67.1 \%$ \\
$45.1-65$ & 10 & 606 & $60.6 \%$ \\
$25.1-45$ & - & - & - \\
$0.0-25$ & - & - & - \\
Jumlah & 34 & 2762.8 & $77.57 \%$ \\
Kategori & & & Tinggi \\
\hline
\end{tabular}

Dari data analisis respon siswa di atas, diperoleh nilai 00-25 sebanyak 0. Nilai 25,1-45 sebanyak 0, nilai 451-65 sebanyak 10, nilai 65.1-85 sebanyak 7, dan nilai 85.1-100 sebanyak 17 orang. Sehingga setelah persentase didistribusikan dalam rumus memperoleh persentase sebesar nilai 00-25 sebanyak 0\%, nilai 25,1-45 sebanyak 0\%, nilai 45,1-65 sebanyak $60.6 \%$, 
nilai $65,1-85$ sebanyak $67.1 \%$, dan nilai $85,1-100$ sebanyak $90 \%$, dengan jumlah nilai rata-rata respon $77.57 \%$ sehingga setelah dikonversikan ke dalam tabel termasuk kategori tinggi.

\section{Pembahasan}

Berdasarkan hasil analisis di atas pemberian tindakan pada siklus I peneliti berhasil mengajak siswa lebih berperan aktif dalam mengikuti pembelajaran tetapi hasil tersebut belum dapat mencapai hasil yang optimal, hal ini disebabkan karena siswa belum terbiasa menggunakan penerapan model kooperatif tipe Jigsaw. Sedangkan di lihat dari hasil prestasi belajar siswa, pada tingkat awal nilai rata-rata $53.57 \%$ dan dipersentasikan pada siklus 1 $85.71 \%$ sudah mencapai tingkat kesuksesan yaitu di atas rata-rata 75 dan ketuntasan belajar klasikal minimal $85 \%$, namun demikian peneliti belum puas manakala belum membuktikannya dalam langkah berikutnya yakni pada siklus II. Hal ini menyebabkan peneliti melanjutkan dengan pemberian tindakan pada siklus II sebagai penyempurnaan atau perbaikan pada siklus I.

Pada pelaksanaan siklus II dari analisis penunjukan bahwa siswa sudah dapat dikondisikan secara optimal dalam penerapan model kooperatif tipe Jigsaw. Ini terbukti adanya peningkatan baik pada nilai rata-rata, persentase daya serap dan persentase ketuntasan belajar secara klasikal, peningkatan dari pelaksanaan siklus II tersebut dapat dipaparkan bahwa dari $85.71 \%$ ketuntasan siklus I menjadi $100 \%$ sehingga terjadi peningkatan nilai rata-rata $53.57 \%$ pada pembelajaran awal dari rata-rata nilai pada siklus I $85.71 \%$ 2. Persentase ketuntasan nilai sebesar $14.29 \%$.

Sedangkan respon/tanggapan siswa terhadap model pembelajaran yang digunakan selama penelitian ini setelah data hasil angket di analisis, maka diperoleh skor $77.57 \%$, setelah dikonversikan dengan tabel, ternyata respon siswa termasuk tingkat tinggi maka penerapan model kooperatif tipe Jigsaw ini dapat diterima dengan positif (disenangi) oleh siswa kelas XI IPS 1 SMA Negeri 4 Tebo semester I tahun pelajaran 2019/2020, untuk mata pelajaran penjasorkes pada materi kebugaran jasmani.

\section{KESIMPULAN}

Berdasarkan penelitian tindakan kelas yang dilaksanakan pada siswa kelas XI IPS 1 SMA Negeri 4 Tebo, maka dapat ditarik kesimpulan bahwa dari penelitian yang diadakan dengan meneliti kondisi awal siswa yang diukur dengan alat tes tulis dan hasil penelitian tindakan kelas dengan 2 siklus terlihat adanya peningkatan hasil yang dicapai. Siswa dalam menguasai materi yang diberikan peningkatan penguasaan materi ini mulai dari siklus I siswa dapat meningkat sebesar $32,14 \%$ dari kondisi awal, sedangkan dari siklus I setelah dilakukan tindakan pada siklus II meningkat sebesar $14,29 \%$.

Adapun selanjutnya kesimpulan yang dapat diambil juga sebagai berikut: (1) Dengan membawa siswa aktif dalam pembelajaran akan dapat meningkatkan penguasaan materi, kebugaran jasmani dari siswa yang bersangkutan (2) Pembelajaran aktif menggunakan model kooperatif tipe Jigswa merupakan model pembelajaran efektif dalam menyampaikan materi kebugaran jasmani (3) Pembelajaran dalam kelompok kecil dapat meningkatkan kemampuan penguasaan materi dari siswa, selain itu dengan kelompok kecil ini kerjasama diantara siswa dapat tercipta dengan lebih baik (4) Penggunaan lembar kerja untuk membawa siswa agar aktif dalam belajar merupakan langkah yang efektif bagi siswa karena siswa dapat bersosialisasi dan saling tukar informasi dan idea atau langkah-langkah kerja untuk menyelesaikan masalah dengan teman sebayanya.

\section{DAFTAR PUSTAKA}

Ainin, I. K. (2012). Strategi Pembelajaran Pendidikan Jasmani Adaptif: Penelitian Para Guru Guruan Jasmani Adaptif Sekolah Dasar Inklusif Kota Surabaya (Doctoral dissertation, Universitas Guruan Indonesia).

Fathurrohman, M. (2015). Model-Model Pembelajaran. Jogjakarta: Ar-Ruzz Media. 


\section{STRATEGY : Jurnal Inovasi Strategi dan Model Pembelajaran Vol 1. No 2. Oktober Tahun 2021 e-ISSN : 2798-5466 P-ISSN : 2798-5725}

Maisarah, A. (2019). Strategi Belajar Mengajar Dengan Menerapkan Model Demonstrasi Untuk Meningkatkan Prestasi Belajar Penjasorkes Materi Menerapkan Budaya Sehat Pada Siswa Kelas VII SDN 1.2 Pudak Setegal Tahun Pelajaran 2017/2018. Jurnal Langsat, 6(1).

Mulyadi, M. (2018). Strategi Belajar Mengajar Dengan Menerapkan Model Demonstrasi Untuk Meningkatkan Prestasi Belajar Penjasorkes Materi Pertumbuhan Dan Perkembangan Makhluk Hidup Pada Siswa Kelas Vii Smpn 3 Tanjung. Jurnal Langsat, 5(1).

Nopiyanto, Y. E., \& Raibowo, S. (2020). Penerapan model pembelajaran Jigsaw untuk meningkatkan motivasi dan hasil belajar mahasiswa penjas pada mata kuliah filsafat penjas dan olahraga. Journal Of Sport Education (JOPE), 2(2), 61-69.

Nurdyansyah, N., \& Fitriyani, T. (2018). Pengaruh Strategi Pembelajaran Aktif Terhadap Hasil Belajar Pada Madrasah Ibtidaiyah. Universitas Muhammadiyah Sidoarjo.

Nurfitriyanti, M. (2017). Pengaruh model pembelajaran kooperatif tipe jigsaw terhadap hasil belajar matematika ditinjau dari kecerdasan emosional. Formatif: Jurnal Ilmiah Pendidikan MIPA, 7(2).

Pratiwi, N. K. (2017). Pengaruh tingkat pendidikan, perhatian orang tua, dan minat belajar siswa terhadap prestasi belajar bahasa indonesia siswa smk kesehatan di kota tangerang. Pujangga, 1(2), 31.

Putra, I. A., Pujani, N. M., \& Juniartina, P. P. (2018). Pengaruh model pembelajaran kooperatif tipe jigsaw terhadap pemahaman konsep IPA siswa. Jurnal Pendidikan dan Pembelajaran Sains Indonesia (JPPSI), 1(2), 80-90.

Rosyidah, U. (2016). Pengaruh model pembelajaran kooperatif tipe jigsaw terhadap hasil belajar matematika siswa kelas VIII SMP Negeri 6 Metro. SAP (Susunan Artikel Pendidikan), 1(2).

Syafi'i, A., Marfiyanto, T., \& Rodiyah, S. K. (2018). Studi tentang prestasi belajar siswa dalam berbagai aspek dan faktor yang mempengaruhi. Jurnal Komunikasi Pendidikan, 2(2), 115-123.

Siagian, R. E. F. (2015). Pengaruh minat dan kebiasaan belajar siswa terhadap prestasi belajar matematika. Formatif: Jurnal Ilmiah Pendidikan MIPA, 2(2).

Trisianawati, E., Djudin, T., \& Setiawan, R. (2016). Pengaruh model pembelajaran kooperatif tipe jigsaw terhadap hasil belajar siswa pada materi vektor di kelas X SMA Negeri 1 Sanggau Ledo. Jurnal Penelitian Fisika Dan Aplikasinya (JPFA), 6(2), 51-60.

Wijayani, I., Haenilah, E. Y., \& Sugiman, S. (2017). Hubungan Motivasi Belajar dengan Prestasi Belajar Siswa Kelas V. Pedagogi: Jurnal Pendidikan Dasar, 5(16).

Yunus, M., \& Ilham, K. (2014). Pengaruh model pembelajaran aktif tipe giving question and getting answers terhadap hasil belajar siswa kelas X SMA Negeri 1 Bajeng (studi pada materi pokok tata nama senyawa dan persamaan reaksi). Chemica: Jurnal Ilmiah Kimia dan Pendidikan Kimia, 14(1), 20-26. 